\title{
The impact of the economic crisis on the environmental responsibility of the companies
}

\author{
M.M. Miras, B. Escobar, A. Carrasco \\ Accounting and Financial Economics Department, University of Seville, Seville, Spain \\ mmiras@us.es
}

Received: January 24, 2021 Revised: February 20, 2021. Accepted: March 8, 2021. Published: March 24, 2021.

\begin{abstract}
The severe economic crisis is affecting significantly to the environment in which companies have to continue with their business. Consequently, academicians and managers are worried about what is going to happen with the Social Responsibility and particularly with the Environmental Responsibility, due to the decrease in the financial performance of the companies. The aim of this paper is to study the effect of the crisis on the environmental behavior of the Spanish companies through an explicative study, deepening in the comparison between the years 2006 and 2010. As a result, Spanish companies continue carrying out behaving in an environmentally friendly way because their Environmental Scores are growing, despite the decline of the Financial Performance. Moreover, it is identified a change in the factors that affect to the environmental behavior due to the identification of less dependence on corporate financial performance.
\end{abstract}

Keywords- Environmental Responsibility; Crisis, Financial Performance.

\section{INTRODUCTION}

The current financial and economic crisis is been singular given its intensity, complexity and the difficulties that developed countries are finding in overcoming it. Probably if organizations had been taken into account the CSR approach seriously, nowadays we would not be likely involved in the current economic crisis [1] or at least not in such magnitude, but the crisis is a reality as well as the great consequences are been suffered by organizations which range from the closing down of several firms, getting losses, until at the best, a large reduction of the profits.

Since the current economic crisis rose, the priorities of the business have changed becoming the management of the liquidity in one of the most important aspects. Moreover, all the actions are being carried out in accordance with the financial difficulties [2]. Taking into account the uncertain business environment, companies have been forced to redefine their business and implement austerity plans as unique alternative to survive, particularly, they are encouraged to reduce the expenses [3] which could imply revoking to their social and environmental responsibilities because them generates costs [4] or the delay or cancellation of many CSR initiatives [5].
However, it's no less true that the number of social needs has been increased during these rough times, so the CSR actions are more necessary than ever [3], being more necessary than ever to emphasize the relevance of CSR actions carried out by the organizations for the societal well-being. Hence, society asks companies being more involve in supporting social and environmental causes [6].

In this context, both academicians and practitioners are asking about how Corporate Social Responsibility (hereinafter CSR) and all its dimensions according to the Triple Bottom Line approach (Social, Environmental and Economic) are going to be influenced by these extraordinary circumstances.

In addition, these circumstances may be well allowed to understand better and more clearly what are the real motivations or interests of conducting Social or Environmental policies for firms, and provides a perfect opportunity to test the real commitment of the companies with the CSR approach [7]. If companies only implement CSR actions looking for legitimacy or direct benefits (short-term vision), the CSR should be drastically affected by the crisis. However, if organizations are really engaged with these issues and they have really integrated CSR in their business strategy, they could take advantage of the crisis as an opportunity instead of considering it such as a threat $[1,8]$. Therefore, the present crisis may not mean directly the disappearance of CSR actions, although the amount could be reduced due to main causes [9].

Despite the importance of this issue and the large number of explications found in the literature, there is little empirical evidence about what is happening in the different countries.

While in [3] is analyzed if in the context of the companies listed in Fortune 500 there was a change in the number and extend of CSR projects in 2008 -being in the deep of the crisis-, others investigated the influence on the CSR performance in some companies included in the GRI report list since 2007 until 2010 [10]. On the other hand, others evaluated the CSR behavior of the companies during 2007 until 2009 [11]. Likewise, in [5] is examined how the multinational firms in Kenya were being affected by the economic downturn whereas in [12] is studied the impact on the USA companies. Indeed, the general conclusion we can report from the articles analyzed is that the firms had improved their CSR scores in spite of the consequences of the economic downturn. Nevertheless, it 
seems to be a significant drop in the level of CSR during the last period studied (2009-2010).

Nevertheless, it was found that the relationship between CSR and FP in France had changed due to the uncertain environment of the crisis going from a strong relationship between the variables to an insignificant connection, being the second semester of 2007 the break-point [13].

The present economic crisis has been made deeper and longer in Spain than other countries, so the results and the evidence from the articles discussed previously can not be extrapolated. There are several reasons why we are so interested in studying the consequences of the financial crisis on the social and environmental behavior in Spain, and why it could be different from other countries [14].

One of the reasons why the Spanish economy has been severely affected by the present situation is due to the lack of balance that had been generated during the boom phase. It has made to Spanish economy particularly vulnerable to changes in the macroeconomic and financial conditions, so the consequences of the global international crisis are being worse than others European countries.

Due to the pronounced expansion experienced by the Spanish economy in the previous period -with annual GDP growth above $4 \% 0^{-}$, it is more highlighted the sharp decline that is experiencing the employment (with an unemployment rate of around $25 \%$ ), the difficulties facing the recovery as well as the higher risks from the possible fall. In this sense, the adjustment phase is being conditioned by certain idiosyncratic features of the Spanish economy -the shocks have affected Spain more than neighboring countries- and by certain institutional characteristics that affect the adjustment mechanisms.

Moreover, according to [14], the crisis has had a direct impact on the business activity in Spain. Such report reveals that at least $65 \%$ of Spanish firms maintained or increased their investment in CSR in 2010, although it is also shown that one in three companies stopped performing CSR as a direct consequence of the crisis. It is also noted in the report that the behavior of big companies and the small ones differs considerably, the latter being those that have absorbed most of the reductions in CSR.

Additionally, in the report we can see that in Spain the environmental actions have being identified such as one of the higher priorities in order to decide if a company is committed with the CSR approach.

Despite the difficult situation that is happening in the Spanish economy, it seems that the commitment of the firms with the socially and environmentally responsible behavior has not lost its strength.

So taking into consideration that Spain is one of the countries that is been more affected by the current financial situation, the effect of the crisis on the environmental dimension of the CSR in Spain could be different from other countries, we are going to test if Spanish companies continue behave in a Environmentally friendly way, through the comparison between the years 2006 (before the crisis started) and 2010 (when the crisis was wreaking havoc).

\section{MATERIAL AND METHOD}

It is undeniable the evolution that Corporate Social Responsibility has suffered in importance and significance over the last decades $[15,16]$. It has changed from an irrelevant or fashionable idea to one of the most widely accepted concepts in the business world $[17,18]$.

Although the idea that firms had some responsibilities to society beyond that making profits has been around for centuries [15], it has not been until the end of the last century when CSR was become in a reality in business and one of the determinants factor that has been taking into account in the decision-making $[19,20]$. It is why most of the international organizations have established guidelines (i.e. Global Reporting Initiative - GRI) and recommendations about how to be a socially and environmentally responsible company, the reason of a high increment in the number of voluntary social disclosure memories of the companies as well as the creation of Sustainability Stock Indexes -Dow Jones Sustainability Index, KLD Domini, FTSE4Good, between others- [21].

One of the main debates about CSR, is the one refers to its relationship with the FP. In that sense, there are several theories that try to explain this complex relationship [22]. In this regard, this paper is focused in the effect of the Financial Performance (FP) on the Environmental Responsibility due to the current economic crisis is affecting seriously to the financial outcomes of the companies. Hence, it is necessary to describe the different approaches that try to explain this relation.

On the one hand, the Slack Resources Hypothesis argued that companies will be more or less environmentally responsible depending on their availability of financial resources [23]. Achieving a better performance will allow making great investments in environmental projects. Consequently CSR will only be viable in companies with solid and sustainable financial results, i.e., some authors, such as [24] emphasizes that CSR is a luxury that can only be borne by buoyant companies.

Moreover, the Managerial Opportunism Hypothesis reported by $[25,26]$ discussed that the purposes of the managers may be different from those of the shareholders and other stakeholders. This is due to the managers' objectives being oriented towards the short-term and immediate profitability, while the owners' objectives are more linked to the long term.

In accordance with these hypotheses, the high cost of the Environmental initiatives would be the responsible of a drastic reduction of this kind of actions being it even higher if we based on the second theoretical approach. It is because managers worried by the financial situation prefer to decrease all the cost that they are not sure about their short-term benefits because their main concern is their survival at the company. So the present financial situation would be triggered a large diminution of the environmental activities or policies, so our first Hypothesis would be:

$H_{1}$ : The companies are less environmentally responsible due to the economic crisis. 
This conflict of interest between managers (agents) and owners (principals) has also been developed by the Agency Theory [27]. Notwithstanding, in order to avoid the managerial opportunism [28], some mechanisms (financial rewards, shares) were specified so that the interest of the shareholders has to be taken into account [29, 30]. In addition, during a crisis period, directors and shareholders should come to an agreement about the strategic decisions of the companies, so managers pressured by shareholders could choose continuing with CSR policies because they understand that it could be a good way to manage the economic crisis and they could be more concerned about long-term repercussions, so our second hypothesis would be:

$\mathrm{H}_{2}$ : Despite of the crisis, companies continue to behave in an environmentally responsible way.

In addition, it must be kept in mind that the impact of the crisis on the CSR actions can have time lags [4], so it is important to analyze the influence in the current year and the next.

$H_{3}$ : The Environmental Responsible behaviors of the companies are affected by the performance obtained the previous year.

In order to achieve our aims, firstly, we made a descriptive analysis that helps us to understand the evolution and what is happening with the Environmental Scores and the financial measures from 2006 to 2010 . After that, to test the first and the second hypotheses proposed, we have carried out two linear regressions to evaluate if the environmental friendly behaviors have been affected by the FP obtained, in 2006 (before the crisis started) and in 2010 (when the crisis was wreaking havoc), to compare if the influence of the performance on the behavior has changed due to the crisis. Moreover, to test the third hypothesis, we made two extra regressions to see if the FP of the previous year has influenced on the environmental behavior of the firms in 2006 and 2010.

The sample was initially composed by all the Spanish firms included in the IBEX-35, although seven of them had to be excluded due to the lack of data availability, so the final sample was compounded of 28 companies whose data were provided by the DataStream Professional database and ASSET4 database.

The variable used in the study to measure the Environmental Responsible Behavior is the Environmental Score (range from 0 to 100) provided by ASSET4 database [31]. This Score measures a company's impact on living and non-living natural systems, including the air, land and water, as well as complete ecosystems.

Due to the lack of agreement in the literature about what is the best indicator to measure the FP, we are going to use the ROA and the ROE (such as traditional indicators) and the Economic Score (value between 0 and 100) provided by ASSET4 database (Appendix 1) because it includes some intangibles measures of the client loyalty, performance and shareholder loyalty apart from taking into account the traditional financial measures.

\section{RESULTS AND DISCUSSION}

As mentioned previously, the aim of the paper is to analyze empirically the influence of the crisis on the Environmental responsibilities of the most representative firms in Spain. The results are divided into two parts as follows: firstly, it has been examined the evolution of the four variables studied -using the mean values- in order to be able to get a general idea of the increase or decrease of the scores when the crisis began and secondly, we are going to carry out linear regressions to test the influence of the FP on the Environmental Responsibilities (Model 1), comparing the situation in 2006 to 2010 and taking into account the time lags (Model 2).

The evolution of all the variables considered from 2006 to 2010 is shown in Figures 1 and 2, and we could report that the Environmental Scores is growing year by year in spite of the economic downturn, that we could easily identify by the behavior of the three different measures of the FP. It's so relevant because the CSR behaviors of the companies have not being interrupted or delayed by the financial crisis as in other countries in which significant reductions were identified in the last two studied periods $[3,10,11]$.

It disagrees with the evidence found on the Spanish Savings Banks [7], so this fact shows that the conclusions of a particular industry could not be generalized. Notwithstanding, this evidence agrees with [14], because this report argues that large companies in Spain continue to have a commitment with the CSR, although the situation of small firms is not the same.

Fig. 1: Evolution of the Environmental and Economic Scores

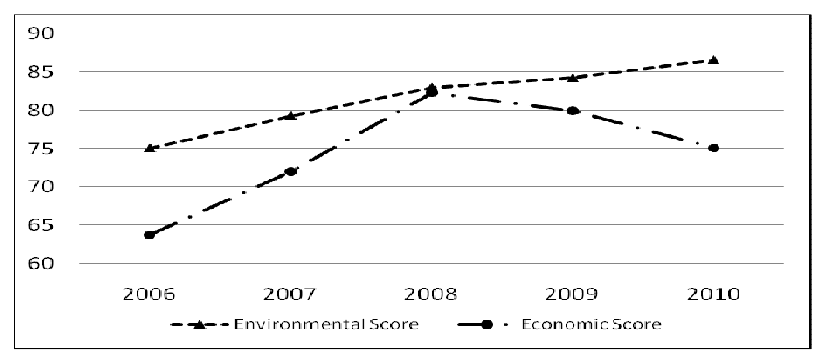

Fig. 2: Evolution of the ROA and ROE indicators

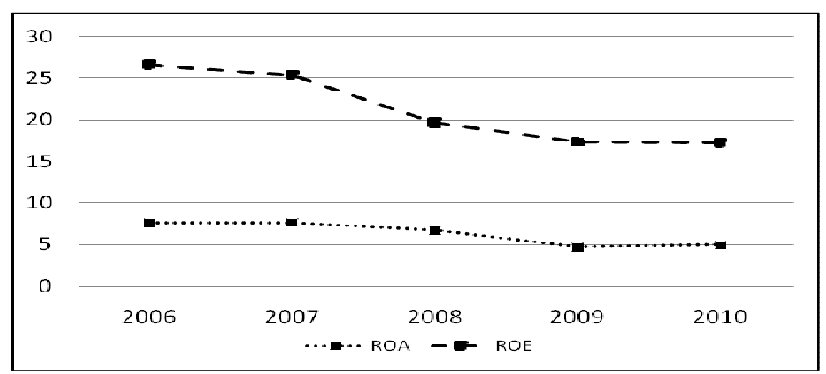


TABLE I. ESTIMATION OF MODEL 1.

\begin{tabular}{|c|c|c|c|c|c|c|}
\hline & ENV Score 2006 & ENV Score 2006 & ENV Score 2006 & ENV Score 2010 & ENV Score 2010 & ENV Score 2010 \\
\hline Constant & $46.375(5.56)^{* * *}$ & $72.294(10.19)^{* * *}$ & $75.783(6.07)^{* * *}$ & $82.401(12.04)^{* * * *}$ & $85.505(25.44)^{* * * *}$ & $87.028(25.22)^{* * *}$ \\
\hline Eco_Score $_{t}$ & $0.449(3.84)^{* * *}$ & & & $0.056(0.64)$ & & \\
\hline $\mathrm{ROA}_{t}$ & & $0.366(0.51)$ & & & $0.22(0.40)$ & \\
\hline ROE $_{t}$ & & & $-0.271(-0.06)$ & & & $-0.025(-0.15)$ \\
\hline F & $14.76 * * *$ & 0.26 & 0 & 0.41 & 0.16 & 0.02 \\
\hline$\overline{\mathbf{R}^{2}}$ & 0.3622 & 0.0101 & 0.0001 & 0.0155 & 0.0061 & 0.0009 \\
\hline
\end{tabular}

Table 1 reports the results of the linear regressions made in order to see what the influence of the different measures of FP on the Environment Score is (Model 1) as well as to compare the scenario after and during the crisis.

Firstly, it is relevant to mention the differences between the analyses taking into account different measures of FP. While the Economic Score predicts in a $36 \%$ (in 2006) the Environmental Score, the predictions of the others measures are not significant. Moreover, we can see that any of the financial measure gets a good prediction of the Environmental Score. It could be explained by a change in the factors that influence on the Environmental behavior of the Spanish companies, being now more committed with the real extend than with the potential financial rewards of them. These results are consistent with the evidence found by [13] in France, who reported that since 2007 there has been a change in the behavior of this relationship.

In Table 2, it is presented the estimation of the Model 2 which is focused on the time lags. In this test, due to the results of the model 1's estimation, we only test the time lags with the Economic Score. It is highlighted that the FP of the previous year has a bigger and more significant effect on the Environmental Score than the performance of the year, regardless the year we are testing. Moreover, the percentage of the Environmental Score explained by them is higher than in Model 1. Then, the environmental behavior of the companies is more influenced by the FP of the previous year.

In spite of the influence of the previous performance on the CSR, the difference in the percentages in which CSR is explained by the FP between the two years considered remains. This fact allows us to further support the results shown by Model 1, confirming that there is a change in the factors that determine the environmental responsible behavior of the companies.

TABLE II. Estimation OF MODEL 2.

\begin{tabular}{|c|c|c|}
\hline & $\begin{array}{l}\text { Model } 2 \\
\text { ENV Score } 2006 \\
\end{array}$ & $\begin{array}{l}\text { Model } 2 \\
\text { ENV Score } 2010\end{array}$ \\
\hline Constant & $42.536(5.25)^{* * *}$ & $71.411(11.67)^{* * *}$ \\
\hline Eco_Score $_{t}$ & $0.196(1.18)$ & $-0.284(-2.58)^{*}$ \\
\hline Eco_Score $_{t-1}$ & $0.336(2.03)^{*}$ & $0.457(3.98) * * *$ \\
\hline $\mathbf{F}$ & $10.32 * * *$ & $8.24 * * *$ \\
\hline $\mathbf{R}^{2}$ & 0.4522 & 0.3973 \\
\hline
\end{tabular}

The results are surprising one hand-because in no other empirical work had been obtained CSR increases during 2010 but otherwise they confirm the evidence shown by [14]. Therefore, it is reinforced the idea that Spanish big companies during the crisis continue taking into consideration the CSR approach, trying to behave in an environmental responsible way.

It is important to see that the Environmental Score is close to the maximum level, so it is true that the scope for improvement of firms each year is more reduced and therefore each year is more complicated to get significant improvements in the Score. Then, the results confirm that the commitment of the Spanish companies with the Environment is increasing year by year.

After the descriptive analysis of the findings and trying to connect them with the theoretical framework, we could say that the results show that shareholders are influencing in strategic decisions of the companies as, so it supposes to accept the Hypothesis 2 and reject Hypothesis 1. Thus, in the light of the results, we can conclude that listed Spanish firms have adopted a long-term approach to manage the environmental dimension of CSR. So they are trying to continue doing Environmental policies, although in most of the cases it involves making significant changes in their strategies to adapt it at the new financial circumstances.

A relevant change has been identified about the factors that affect to the Environmental behavior. While in 2006, the Economic Score from the same year explained at least a $36 \%$ of the Environmental Scores obtained, it was only a $1.5 \%$ of the Scores in 2010. Hence, we could clearly conclude that the FP has left to be the most influenced factor on CSR. The direct implication is that we have to search which factors explains nowadays the Environmental Behavior of the companies.

Regarding the paper's limitations, it only has been analyzed the companies listed in the IBEX-35 Index, so the conclusions couldn't be extrapolated to all the Spanish companies and particularly to the Small and Medium companies because they are completely different from the studied firms.

\section{REFERENCES}


[1] B. Fernandez, "Crisis and Corporate Social Responsibility: Threat or Opportunity?" International Journal of Economic Sciences and Applied Research. 2009; 2(1): 36-50.

[2] N. Yelkikalan and C. Köse, "The Effects of the Financial Crisis on Corporate Social Responsibility," International Journal of Business and Social Science. 2012; 3(3): 292-300.

[3] Y. Z. Karaibrahimoglu, "Corporate social responsibility in times of financial Crisis," Afr J Bus Mana 2010; 4(4): 382-389.

[4] M. Orlitzky, F.L. Schmidt and S.L. Rynes, "Corporate Social and Financial Performance: A Meta-Analysis," Organ Stud. 2003; 24(3): 403-441.

[5] J. Njoroge 2009, "Effects of the global financial crisis on corporate social responsibility in multinational companies in Kenya", Covalence Intern Analyst Papers, available at: www.covalence.ch/docs/KenyaCrisis.pdf accessed on 30 December, 2009.

[6] F.G. Grigore, "Corporate Social Responsibility and Marketing," in Developments in Corporate Governance and Responsibility. 2011; 2: $41-58$.

[7] B. Escobar and M.M. Miras, "Spanish Savings Banks' Social Commitment: just pretty words?," Social Responsibility Journal. 2013; 9(3), 427-440.

[8] D. Krali, "Leading "Greenovate" Change," In: V. Perminov, J. Nunes and N. Mohareb editors. Advances in Environmental Science and Sustainability. WSEAS Press, 2012; p-81-86.

[9] A. Branca, J. Pina, M. Catalao-Lopes, "Corporate Social Responsibility and Macroeconomic Environment," In: M. Mastorakis, V. Mladenov, J. Savkovic-Stevanovic editors. Recent Researches in Sociology, Financing, Environment and Health Sciences. WSEAS Press, 2011; p223-228.

[10] C. Giannarakis and I. Theotokas, "The Effect of Financial Crisis in Corporate Social Responsibility Performance," International Journal of Marketing Studies. 2013; 3(1): 2-10.

[11] G. Charitoudi, G. Giannarakis and T.G. Lazarides "Corporate Social Responsibility Performance in Periods of Financial Crisis," European Journal of Scientific Research. 2011; 63(3): 447-455.

[12] J.A. Arevalo and D. Aravind, "The impact of the crisis on corporate responsibility: the case of UN global compact participants in the USA," Corporate Governance. 2010; 10(4): 406-420.

[13] I. Ducassy, "Does Corporate Social Responsibility Pay Off in Times of Crisis? An Alternate Perspective on the Relationship between Financial and Corporate Social Performance", Corporate Social Responsibility and Environmental Management. 2013; 20(3):157-167.

[14] Foretica Report, "Evolución de la Responsabilidad Social de las empresas en España" 2011.

[15] A.B.Carroll and K.M. Shabana, "The Business Case for Corporate Social Responsibility: A Review of Concepts, Research and Practice," Int J Manag Rev. 2010; 12(1): 85-105.
[16] F. Schultz and S. Wehmeier, "Institutionalization of corporate social responsibility within corporate communications: Combining institutional, sensemaking and communication perspectives," Corporate Communications: An International Journal. 2010; 15(1): 9-29.

[17] B. Argandoña, "La Responsabilidad Social de la Empresa a la luz de la Ética," Contabilidad y Dirección. 2007; 27-37.

[18] M.D.P. Lee, "A review of the theories of corporate social responsibility: Its evolutionary path and the road ahead," Int J Manag Rev. 2008; 10(1): $53-73$.

[19] M. Nieto and R. Fernández, "Responsabilidad social corporativa: la última innovación en management," Universia Bus Rev. 2004; 1: 28-39.

[20] E. Garriga and D. Melé, "Corporate Social Responsibility Theories: Mapping the Territory," J Bus Ethics. 2004; 53(1): 51-71.

[21] M. Maletič, D. Maletič and B. Gomišček, "An organizational sustainability performance measurement framework," In: R.A. Rodrigues Ramos, I. Straupe, T. Panagopoulos editors. Recent Researches in Environment, Energy Systems and Sustainability. WSEAS Press, 2012; p-220-225.

[22] L.E. Preston and D.P. O'Bannon, “The Corporate Social-Financial Performance Relationship: A Typology and Analysis," Bus Soc. 1997; 36:419-429.

[23] S.A. Waddock and S.B. Graves, "Corporate Social PerformanceFinancial Performance Link," Strategic Manage J. 1997; 18 (4): 303319.

[24] J.A.M. Izquierdo, "Responsabilidad social corporativa y competitividad: una visión desde la empresa," Revista valenciana de Economía y Hacienda. 2004; 12: 9-50.

[25] O.E. Williamson, "The Economics of Discretionary Behavior: Managerial Objectives in a Theory of the Firm," Chicago: Markham, 1967.

[26] O.E. Williamson, "The Economic Institutions of Capitalism," New York, Free Press, 1985.

[27] S.A. Ross, " The Economic Theory of Agency: The Principal's Problem," Am Econ Rev. 1973; 63(2): 134-139.

[28] J.L. Miller, “ The Board as a Monitor of Organizational Activity: The Applicability of Agency Theory to Nonprofit Boards," Nonprofit Management and Leadership. 2002, 12(4): 429-450.

[29] M.C. Jensen and H.W. Meckling, "Theory of the firm: managerial behavior, agency costs, and ownership structure," J Financ Econ. 1973; 3: $305-360$.

[30] K.M. Eisenhardt, "Agency Theory: An Assessment and Review," Acad Manage Rev. 1989; 14(1): 57-74.

[31] I. Ioannou and G. Serafeim, "What drives corporate social performance?: The role of nation-level institutions," J Int Bus Stud. 2012; 43(9): 834-864.

\section{Creative Commons Attribution License 4.0 (Attribution 4.0 International, CC BY 4.0)}

This article is published under the terms of the Creative Commons Attribution License 4.0 https://creativecommons.org/licenses/by/4.0/deed.en_US 